Original Article

\title{
CLOSTRIDIUM BOTULINUM SPORES FOUND IN HONEY FROM SMALL APIARIES IN POLAND
}

\author{
Joanna Wojtacka ${ }^{1 *}$ \\ Beata Wysok ${ }^{1}$ \\ Zbigniew Lipiński \\ Małgorzata Gomółka-Pawlicka' \\ Helena Rybak-Chmielewska ${ }^{3}$ \\ Agnieszka Wiszniewska-Łaszczych ${ }^{1}$
}
${ }^{1}$ Chair of Veterinary Public Health, Faculty of Veterinary Medicine, University of Warmia and Mazury in Olsztyn, Poland
2 Department of Hormonal Action Mechanisms, Institute of Animal Reproduction and Food Research, the Polish Academy of Sciences
${ }^{3}$ Research Institute of Horticulture, Apiculture Division in Puławy, Poland
*corresponding author: joanna.wojtacka@uwm.edu.pl
Received: 15 February 2016; accepted: 26 May 2016

A bstract

A total of 102 honey samples collected from small apiaries ( $\leq 20$ hives) in Poland were analysed for the presence of Clostridium botulinum spores. The samples were prepared using the dilution centrifugation method and cultured in parallel in cooked meat medium (CMM) and tripticase peptone glucose yeast (TPGY) enrichment broths. Identification of toxin types A, B, and E of Clostridium botulinum strains was performed with the use of the multiplex PCR method. Positive samples were also subjected to quantitative analysis with the use of Clostridium botulinum Isolation Agar Base (CBAB). The prevalence analysis showed $22(21.6 \%)$ samples contaminated with $C$. botulinum spores. The major serotype detected was botulin neurotoxin type A - $16(72.7 \%)$ whereas type B was found in $3(13.6 \%)$ honey samples and type $E$ also only in $3(13.6 \%)$ honey samples. Dual-toxinproducing strains were noted. The average quantity of spores in PCR - C. botulinum positive samples was 190 in 1 gram of honey.

Keywords: Clostridium botulinum, honey, PCR, Poland, spores

\section{INTRODUCTION}

Clostridium botulinum is an ubiquitous and anaerobic, gram-positive, spore-formingrod, that produces protein neurotoxin and heat-resistant endospores (Sharma et al., 2006). The genomes of many clostridia have been sequenced and are available online (WHO Fact Sheet, 2013). Clostridium botulinum neurotoxin type $A$ (BoNT/A) is the most potent neurotoxin known (Arnon et al., 2001; Horowitz, 2005). There аге seven serotypes: $A, B, C, D, E, F, G$ of Clostridium botulinum distinguished based on antigenic differences among Botulinum Neurotoxin (BoNT), (Rudnicka et al., 2015). The human pathogenic $C$. botulinum strains are divided into groups I (pro- teolytic and mesophilic) and II (non-proteolytic and psychrotrophic) based on their phenotype. Group I cultures produce toxin A, B or F and group II cultures produce toxin B, E or $F$ (Lindström \& Korkeala, 2006).

The spores of $C$. botulinumare found throughout the world in soil (including sea sediments) and in low numbers in the gastrointestinal tracts of some birds, fish, and mammals. However, the spores of this bacteria do not germinate in soil (Volkova \& Siniak, 1989). Their distribution in the soil is sometimes highly regional (Smith, 1979). In the United States, the most frequent isolate from the soil is type $A$, followed by $B$, and $E$, with an occasional isolate of type $F$. Whereas in Iran, $18 \%$ of honey samples analysed were positive, 
and the proportion of type B was about 90\% while the prevalence of type $A$ was shown to be much lower (Babapour et al., 2015). The reason for such a distribution of the analysed types of C. botulinum spores is unknown.

In Europe, type $B$ is the most frequent isolate, whereas $A$ is comparatively rare (Wells \& Wilkins, 1996). Serotype B is most prevalent in soil. Serotype $E$ is found in sediments in the European zones with a moderate climate e.g. in Norway, Sweden, Denmark, the Netherlands, the Baltic coast of Poland, and Russia (Huss, 1980), although serotypes $C$ and $D$ are also commonly found (Woudstra et al., 2012).

Types $A, B, E$, and infrequently $F$ cause botulism in humans whereas type $C$ of BoNT affects humans sporadically. Types C, D, and $E$ cause botulism in mammals, birds, and fish. There is evidence that live fish can represent a significant vector for the transfer of type $E$ to birds (Yule et al., 2006). In horses, the most common type in North America and Europe is type B (>85\% of the cases in USA), (Dahlenborg, Borch, \& Radstro, 2001; WHO Fact Sheet, 2013). The exact incidence of botulism in animals is not known, but it is relatively low in cattle and horses, and probably more frequent in chickens, and high in wild waterfowl (Stämpfli, 2014).

In nature, $C$. botulinum spores are disseminated with feces, mainly by wild animals including fowl. As a result, they are attached to soil particles and spread long distances by wind, and are deposited on plants or even enter hives directly. The spread of spores is enhanced by excessive domestic animal production, massive transport or movement of animals, deforestation flooding or even meadow over-grazing (Gale et al., 2009;. Huhtanen, Knox, \& Shimanuki, 1981). Interestingly, no C. botulinum spores were found in the intestinal or rectal contents of the bees 2 weeks or more after spore ingestion (Yule et al., 2006). In some cases heavy contamination of honey with $C$. botulinum spores may be associated with dead bees in which $C$. botulinum had proliferated (Nakano, Kizaki, \& Sakaguchi, 1994) or may even be associated with bee feces (Gilbert et al., 2006). Such bees are found on the bottom board, mainly in so called non-hygienic colonies with a low range of debris and a low rate of bee cadaver removal (Spivak \& Downey, 1998; Palacio et al., 2000). In such circumstances, the bees can directly carry into the hive, $C$. botulinum spores in soil particles, which are attached to the bees' bodies. Bees can also indirectly carry the spores into the hive with collected water, pollen nectar or honeydew (Kędzia \& Hołderna-Kędzia, 2010). In effect the spores appear in honey throughout the whole honey production chain (Nevas et al., 2006) and can subsequently infect humans when swallowed. However, the clinical form of this infection called botulism, appears only in infants from 6 days to 12 months of age, who have an incomplete intestinal microflora (Long, 2001). The majority of cases (94\%) occur in children under 6 months of age (Gilbert et al., 2006).

Clostridium botulinum types involved in infant botulism produce type $A, B$, and to a lesser extent type $E$ toxins (Arnon, 1998). Type $F$ is implicated less often, whereas types $C$ and $D$ are rarely associated with this kind of botulism (Smith, 1979; Sharma et al., 2006). Sporadic cases of infection in adults associated with contaminated deep wounds, achlorhydria, gastro-intestinal operations, stagnant loops of the bowel, were also reported (Critchley, 1991). According to Brook (2007) more than 1500 cases of infant botulism have been confirmed in the USA since it was recognised in 1976.

Poisoning with BoNT produced by this bacteria is rare yet so dangerous, that each case is considered a public health emergency. Since, at the present time, honey quality, integrity, sanitation, and nutrition have been receiving growing international attention (Estevinho et al., 2012), the sources of contamination with C. botulinum (Loncaric et al., 2011; Różańska, 2011; Madras-Majewska, Nowakowska, \& Rosiak, 2014) should be better understood. This is especially important because about $60 \%$ of infant botulism cases in Europe have a history of honey consumption (Aureli, Franciosa, \& Fenicia, 2002). The regulations of the EU do not allow producers to remove any integral ingredient of honey, which make it impossible to get rid of C. botulinum spores (Rudnicka, Tenderenda, \& 
Chmiela, 2013). The recommendation to include a warning on honey jar labels saying that honey should not be given to infants under the age of one, is not required in Poland. Moreover, infant botulism is not registered on the Polish National Institute of Hygiene's list of diseases.

Thus, the aim of our study was to evaluate the prevalence of $C$. botulinum spores in honeys in which the honey came from small Polish apiaries. The locations of small apiaries are usually in the back area of small traditional farms near the barns, stables, open pens, pastures etc. These locations make honey highly susceptible to environmental contamination with the spores. Since such apiaries are often called ecological and promote their honey as part of the diet of the elderly and children, it is necessary to study and test the honey (Roman, Popiela-Pleban, \& Kozak, 2013).

\section{MATERIAL AND METHODS}

\section{Honey samples}

A total of 102 honey samples (one sample $=$ one apiary) including: 37 of multifloral honey, 30 of linden honey, 12 of honeydew honey, 8 of acacia honey, 7 of buckwheat honey, 4 of rape honey, and 4 of nectar-honeydew honey were collected directly from small farm backyard-apiaries (not bigger than 20 hives). The classification of honey-origin was based on the beekeepers statements concerning: the time of harvest, the location and the number of hives. There were also basic sensory features (color, consistency, odor, and taste) used for origin classification according to the Polish Norm "Honey" PN-88 A-77626.". All honey samples were collected from May to August 2014.

\section{Culture in liquid and solid media}

The samples were prepared and processed according to the method described by Küplülü et al. (2006) with reference to the scheme published by Koluman et al. (2013). To process qualitative testing, two enrichment media were used i.e. Cooked Meat Medium (CMM, Himedia) and Tripticase Peptone Glucose Yeast Extract Broth (TPGY, Himedia). The solutions of $10 \mathrm{~g}$ of a honey sample, $90 \mathrm{ml}$ of sterile distilled water, and 1\% Tween 80 (Sigma-Aldrich) were stirred until homogenous, then heated in a water bath at $65^{\circ} \mathrm{C}$ for 30 minutes to inactivate non-spore forming bacteria. The mixture was centrifuged for 30 min at $9000 \times g$. The precipitates were put to $9 \mathrm{ml}$ of CMM and $9 \mathrm{ml}$ of TPGY and covered with sterile paraffin oil. The inoculated broths were incubated in the anaerobic chamber in a $90 \% \mathrm{~N}_{2}$ $5 \% \mathrm{CO}_{2}$, and $5 \% \mathrm{H}_{2}$ atmosphere for 7 - 10 days. The Cooked Meat Medium broth was incubated at $35^{\circ} \mathrm{C}$ for isolation of the proteolytic strain of C. botulinum, and TPGY broth was incubated at $26^{\circ} \mathrm{C}$ for isolation of non - proteolytic strains of C. botulinum. After 7 days of incubation, each culture was examined for turbidity and gas production. Cultures that showed no significant growth within 7 days were re-incubated for an additional 3 days. After 10 days of incubation, those cultures with no significant signs of bacterial growth were classified as negative. All cultures showing turbidity and gas production were used for further analyses. The material taken from the tubes was used to prepare the bacterioscopical slide subjected to Gram staining. Once the presence of bacilli was confirmed, the isolation stage was performed. The material was applied with a loop on the surface of Anaerobic Egg Yolk Agar (EYA, Himedia) and incubated under anaerobic conditions at $35^{\circ} \mathrm{C}$ for $48 \mathrm{~h}$. Typical iridescent colonies with precipitation zones were re-streaked on EYA for aerobic and anaerobic parallel culture at $35^{\circ} \mathrm{C}$ for $48 \mathrm{~h}$. The cultures grown in anaerobic conditions were used for PCR assay.

\section{DNA isolation}

Due to animal welfare reasons, mouse bioassay was not used. Instead a PCR assay was performed to identify the toxin types $A, B, E$ or $F$ of $C$. botulinum strains. DNA was isolated from typical colonies obtained on the EYA plates and transferred to $1.5 \mathrm{ml}$ microtubes containing TPGY broth. The specimens were centrifuged at $12000 \times \mathrm{g}$ for $10 \mathrm{~min}$. The sediment obtained was suspended in Tris buffer. DNA isolation was performed with the use of Genomic-Mini Kit (A\&A Biotechnology), according to the producer's instruction. 


\section{PCR reaction}

Multiplex PCR was carried out in a mixture containing: $5 \mu 10 \times$ PCR buffer, $10 \mu l(5 \mathrm{mM})$ $\mathrm{MgCl}_{2}, 5 \mu \mathrm{l}$ dNTPs (final concentration $200 \mathrm{mM}$ ), $0.5 \mu$ leach of forward and reverse primers (final concentration $0.1 \mathrm{mM}$ ) for bont/A, bont/E genes and bont/B, bont/F genes, respectively, $2 \mu$ Taq DNA polymerase, $5 \mu$ template DNA and DNase- and RNase-free deionised water to a final volume of $50 \mu$. This mixture containing all of the above was then transferred to a thermocycler (Mastercykler, Eppendorf). The PCR primers are given in Table 1 . The reaction cycle amplification products obtained was compared with the $100 \mathrm{bp}$ molecular weight marker. The strains classified as $A, B$, and $E$ were additionally compared with reference $C$. botulinum strains from NCTC (National Collection of Cultures Types): NCTC 887, NCTC 3815, and NCTC 8266. DNA of the reference $C$. botulinum strains was used as a positive control for multiplex PCR reaction presented in the study.

\section{Quantitative analysis}

Quantitative testing aimed at determining the number of Clostridium spp. spores in honey samples, was performed on the rinse solutions.

PCR primers used in the study.

\begin{tabular}{|c|c|c|c|c|}
\hline $\begin{array}{l}\text { Toxin } \\
\text { type }\end{array}$ & Primer & Sequences $\left(5^{\prime}-3^{\prime}\right)$ & $\begin{array}{l}\text { PCR } \\
\text { product } \\
\text { size } \\
\text { (bp) }\end{array}$ & References \\
\hline A & $\begin{array}{l}10 A_{f} \\
I O A_{r}\end{array}$ & $\begin{array}{l}\text { GGG CCT AGA GGT AGC GTA RTG } \\
\text { TCT TYA TTT CCA GAA GCA TAT TTT' }\end{array}$ & 101 & $\begin{array}{c}\text { Fenicia et al. } \\
\quad(2007)\end{array}$ \\
\hline B & $\begin{array}{l}\text { CBMLB }_{f} \\
\text { CBMLB }_{r}\end{array}$ & $\begin{array}{l}\text { CAG GAG AAG TGG AGC GAA AA } \\
\text { CTT GCG CCT TTG TTT TCT TG }\end{array}$ & 205 & $\begin{array}{l}\text { Lindstrom } \\
\text { et al. } \\
\text { (2001) }\end{array}$ \\
\hline$E$ & $\begin{array}{l}\text { CBMLE }_{f} \\
\text { CBMLE }_{r}\end{array}$ & $\begin{array}{l}\text { CCA AGA TTT TCA TCC GCC TA } \\
\text { GCT ATT GAT CCA AAA CGG TGA }\end{array}$ & 389 & $\begin{array}{l}\text { Lindstrom } \\
\text { et al. } \\
\text { (2001) }\end{array}$ \\
\hline $\mathrm{F}$ & $\begin{array}{l}\mathrm{CBMLF}_{f} \\
\mathrm{CBMLF}_{\mathrm{r}}\end{array}$ & $\begin{array}{l}\text { CGG CTT CAT TAG AGA ACG GA } \\
\text { TAA CTC CCC TAG CCC CGT AT }\end{array}$ & 543 & $\begin{array}{l}\text { Lindstrom } \\
\text { et al. } \\
\text { (2001) }\end{array}$ \\
\hline
\end{tabular}

${ }^{\mathrm{a}} \mathrm{R}=\mathrm{A}$ or $\mathrm{G}$

b $\mathrm{Y}=\mathrm{Cor} \mathrm{T}$

Table 1

for PCR consisted of an initial denaturation at $9^{\circ} \mathrm{C}$ for $15 \mathrm{~min}, 30$ repetitions of denaturation at $94^{\circ} \mathrm{C}$ for $30 \mathrm{~s}$, annealing at $60^{\circ} \mathrm{C}$ for $30 \mathrm{~s}$, and extension at $72^{\circ} \mathrm{C}$ for $85 \mathrm{~s}$. The final extension was at $72^{\circ} \mathrm{C}$ for $3 \mathrm{~min}$. The amplified PCR products were visualised in $2 \%$ LSI agarose gel in TAE buffer. The stain used was ethidium bromide at a $5 \mathrm{\mu g} / \mathrm{ml}$ concentration. Electrophoresis was performed with the use of the horizontal electrophoresis system Sub-Cell'GT Cell Bio-Rad at $100 \mathrm{~V}$ for $60 \mathrm{~min}$. Visualisation of DNA fragments after electrophoresis was performed on the UView Transiluminator (Bio-Rad). The weight of
This stage included only samples with a confirmed presence of $C$. botulinum spores identified by PCR assay. The volume of $90 \mathrm{ml}$ of $0.1 \%$ peptone water was added to a $10 \mathrm{~g}$ honey sample, homogenised in a stomacher, and heated at $65^{\circ} \mathrm{C}$ for 30 minutes. Then, serial 10 - fold dilutions were performed in PBS. The volume of 100 $\mathrm{\mu l}$ from the initial and following dilutions, was applied to the surface of the $C$. botulinum Isolation Agar Base (CBAB, Himedia). The plates were incubated anaerobically at $35^{\circ} \mathrm{C}$ for $48 \mathrm{~h}$. After this time period, the number of $C$. botulinum spores was counted for each honey sample analysed. 


\section{Statistical analysis}

Statistical analyses were performed using Statistical software 9PL. Differences in the number of spores in $1 \mathrm{~g}$ of the honey sample (in honeys of different types) were analysed with the use of Tukey's test. The chi-square $\left(\chi^{2}\right)$ test was used to estimate the differences in the number of spores isolated based on the type of medium (CMM and TPGY). The statistical significance was accepted with a probability value (p) of 0.05 or less (confidence interval $\mathrm{Cl}=95 \%$ ).

\section{RESULTS}

Of the 102 honey samples, there was gas production and turbidity confirming the presence of anaeronbic bacteria in 24 samples of multifloral honey, 26 samples of linden honey, 9 samples of honeydew honey, and 2 samples of rape honey. An additional 3 days of incubation caused signs of gas production and turbidity in 3 more samples of linden honey. There were no signs of gas production and turbidity in 38 (37.25\%) of the analysed samples. All positive 64 samples

Table 2

Prevalence of $C$. botulinum types A, B, and $E$ in Polish directly-sold honey as detected by PCR

\begin{tabular}{|c|c|c|c|}
\hline Honey type & $\begin{array}{c}\text { Number of } \\
\text { samples } \\
\text { analysed }\end{array}$ & $\begin{array}{l}\text { Number of mPCR } \\
\text { positive samples }\end{array}$ & $\begin{array}{c}\text { Number (\%) of } \\
\text { detected BoNT types }\end{array}$ \\
\hline \multirow[b]{2}{*}{ Multifloral } & \multirow[b]{2}{*}{37} & \multirow{2}{*}{$\begin{array}{c}8 \\
(21.6 \%)\end{array}$} & $\begin{array}{l}\text { Type A } \\
6(75 \%)\end{array}$ \\
\hline & & & $\begin{array}{l}\text { Type B } \\
2(25 \%)\end{array}$ \\
\hline Linden & 30 & $\begin{array}{c}6 \\
(20 \%)\end{array}$ & $\begin{array}{c}\text { Type A } \\
6(100 \%)\end{array}$ \\
\hline \multirow{3}{*}{ Honeydew } & \multirow{3}{*}{12} & \multirow{3}{*}{$\begin{array}{c}3 \\
(25 \%)\end{array}$} & $\begin{array}{c}\text { Type A } \\
1(33.3 \%)\end{array}$ \\
\hline & & & $\begin{array}{c}\text { Type B } \\
1(33.3 \%)\end{array}$ \\
\hline & & & $\begin{array}{c}\text { Type E } \\
1(33.3 \%) \\
\end{array}$ \\
\hline Acacia & 8 & $\begin{array}{c}1 \\
(12.5 \%)\end{array}$ & $\begin{array}{c}\text { Type E } \\
1(100 \%)\end{array}$ \\
\hline Buckwheat & 7 & 0 & - \\
\hline \multirow{2}{*}{ Nectar-honeydew } & \multirow{2}{*}{4} & \multirow{2}{*}{$\begin{array}{c}3 \\
(75 \%)\end{array}$} & $\begin{array}{c}\text { Type A } \\
2(66.7 \%) \\
\end{array}$ \\
\hline & & & $\begin{array}{c}\text { Type E } \\
1(33.3 \%)\end{array}$ \\
\hline Rape & 4 & $\begin{array}{c}1 \\
(25 \%)\end{array}$ & $\begin{array}{c}\text { Type A } \\
1(100 \%)\end{array}$ \\
\hline \multirow{3}{*}{ TOTAL } & \multirow{3}{*}{102} & \multirow{3}{*}{$\begin{array}{c}22 \\
(21.6 \%)\end{array}$} & $\begin{array}{c}\text { Type A } \\
16(72.7 \%)\end{array}$ \\
\hline & & & $\begin{array}{c}\text { Type B } \\
3(13.6 \%)\end{array}$ \\
\hline & & & $\begin{array}{c}\text { Type E } \\
3(13.6 \%)\end{array}$ \\
\hline
\end{tabular}


subjected to Gram staining showed purple rods, sporulating forms, and spores visible as empty spaces inside the purple stain. The culture of these samples on EYA in anaerobic conditions resulted in obtaining a typical white opaque diffuse zone and iridescent sheen colonies in only 44 samples classified for further molecular analyses. The purpose for the further analyses was to confirm and identify the $C$. botulinum toxin types. The presence of $C$. botulinum was confirmed by mPCR assay in 22 (21.6\%) samples of 102 honey samples analysed from the beginning of the laboratory study. The number and distribution of BoNT types (Botulinum Neurotoxin types) of honey samples positive for C. botulinum spores as detected by MPCR, are given in Table 2.

The identification of $C$. botulinum showed that BoNT type A strains were the most numerous. These strains were noted in a total of 16 honey samples whereas type $B$ and $E$ were detected in 3 samples each $(p \leq 0.05)$. The spores of $C$. botulinum type $A$ were found in the majority of the types of positive honey samples analysed, except from acacia honey. The spores of C. botulinum type A were most frequently detected in multifloral, linden, and nectar-honeydew honey, in $75 \%, 100 \%$, and $66.7 \%$ of the positive mPCR samples, respectively. Their prevalence was significantly higher $(p \leq 0.05)$ than in honeydew honey that showed 33.3\% of positive isolates. The spores of $C$. botulinum type $B$ were found only in multifloral and honeydew honey samples. There was no significant difference in their prevalence in these two types of honey ( $p>0.05)$. Type $E$ of $C$. botulinum spores was detected in three types of honey: honeydew, nectar-honeydew, and acacia honey. Taking into account the number of all positive samples within the honey type, there were no significant differences in the prevalence of type $E$ spores between nectar-honeydew and honeydew honey samples. A higher prevalence was observed in acacia honey ( $p \leq 0.05)$, for which one strain of BoNT type $E$ was isolated. None of the samples analysed by MPCR gave a positive result for type F. In our study, honeydew honey was the only type that showed the presence of all three BoNT types (A, B, and $E)$, whereas buckwheat honey samples ( $n=7$ ) were free from C. botulinum spores.

Quantitative analysis showed an average number of 190 Clostridium spp. spores per $1 \mathrm{~g}$ of honey sample. The maximum numbers of spores at a level of 1800 was noted in multifloral honey. In honeydew honey, nectar-honeydew honey, linden honey, acacia honey, and rape honey, the number of spores ranged from 10 to 540 in a $1 \mathrm{~g}$ sample (Fig. 1). However, analysis of the average number of spores between 6 different types of Polish honey showed no statistically significant differences.

\section{DISCUSSION}

Throughout the world, the number and frequency of spores found in honey remain relatively low. Nevertheless, improvements in the identification methods have generated a higher prevalence and higher spore count in honey (Gilbert et al., 2006). A worldwide review of 15 microbial surveys of honey from 1978 to 1991, showed that out of 2033 tested samples, 104 (5.11\%) had been contaminated with $C$. botulinum (Snowdon \& Cliver, 1996).

There is a significant variation in the prevalence of $C$. botulinumin European honeys. For instance, the contamination level of honey in Hungary was $17 \%$, in Turkey it was 19\%, in Denmark 14-20\%, in Italy $11.8 \%$, in Norway 10 - 25\%, in Spain $20 \%$, in the UK 20\%, in Germany 1-20\%, in Sweden 2\% (Nevas et al., 2005; Nevas, 2006; Gilbert et al., 2006; Koluman et al., 2013). The spore prevalence in Danish honey (20\%) is the best example for comparing with the prevalence of C. botulinum spores in small-apiary honey from Poland (a prevalence of 21.6\%), since swine production takes place in both countries. Swine are recognised carriers of BoNT type B (Gilbert et al,. 2006). But the fundamental difference in the prevalence of $C$. botulinum types between Polish and Danish honey is not so obvious since it is type $A$ that prevails in Polish honey $(72.7 \%$ ) while in Danish honey type B (95.2\%) was detected in most samples (Nevas, 2006). The only possible explanation for this difference 
lies in the fact, that the composition of honey microbiota is similar to composition of honeybee microbiota. Such a dependence is closely related to the proximity of farm land, and contamination with C. botulinum spores in the bee pasture around an apiary (Nevas et al., 2006). This effect is also expressed through the number of spores per gram of honey (Nevas et al., 2005) despite hygienic standards during the honey extraction process which are also important (Nevas et al., 2006). This was earlier confirmed by the studies conducted in such different environments as Denmark (Huss, 1980) and the central part of Argentina (Luquez et al., 2005), where a higher prevalence of $C$. botulinum spores was observed in nonvirgin soils than in virgin soils. For example in the temperate zone of Northern America, serotype $A$ is most common west of the Mississippi River, and serotype B east of the Mississippi River (Shapiro, Hatheway, \& Swerdlow, 1998). Small, Polish apiaries are usually located in the back of small traditional farms. These are farms which breed different domestic animals (cattle, pigs, sheep, hens, ducks, geese etc.) These facts seem to explain the reason why, in Poland, there are honeys contaminated with more than one BoNT serotype of C. botulinum. Moreover, the spores are in the soil, mostly because the fields surrounding these apiaries are fertilised with manure from different animal species (cattle and swine, predominantly). Thus, honey samples from small Polish apiaries contained quite a complex C. botulinum spore contamination: $72.7 \%$ of type $A, 13.6 \%$ of type $B, 13.6 \%$ of type $E$, and the emergence of two BoNT types in one sample. Type $E$ seems to have appeared in honey because these apiaries are usually located close to natural water sources that are known as a type $E$ reservoir (Yule et al., 2006). Whereas, Danish honey collected from different size apiaries, (Nevas et al., 2005) located in the areas with more specialised farms, among fields contaminated mostly from pig manure, was almost exclusively contaminated with $C$. botulinum type B (95.2\%); typical for pigs. Type A was only 4.76\% (Dahlenborg, Borch, \& Radstro, 2001; Gilbert et al., 2006; Myllykoski et al., 2006). The above assumption is confirmed by the fact that $62 \%$ of fecal samples from slaughtered pigs in Denmark were almost exclusively contaminated with the spores of type B (Dahlenborg, Borch, \& Radstro, 2001). Moreover, a survey of 47 Danish soil samples from cultivated areas showed a $30 \%$ prevalence rate for $C$. botulinum and most of these were type B spores (Huss, 1980). From 69 terrestrial soil samples taken in Sweden, 20 (29\%) were shown to be positive for $C$. botulinum type $E$, and 1 positive for both types E and B (Johansen, 1963). Interestingly Polish honey samples did not show the presence of $C$. botulinum type $F$ which was found in honey from the Scandinavian countries (Nevas et al., 2005), Turkey (Koluman et al., 2013), and Lithuania (unpubl. data).

Nevertheless, the question remains about why Polish honey was so highly contaminated with BoNT type A which distinctively prevailed over the other serotypes. We presume that $C$. botulinum type $A$ is an ancient soil microbiota member. Its high prevalence is enhanced by intense soil liming by farmers who combat soil acidity by spreading manure on the fields (Ciećko et al., 2001). Type $A$ is usually isolated from soils that are neutral to alkaline (average $\mathrm{pH}$ 7.5), while type B strains were isolated from slightly acidic soils (average pH 6.25), (Gilbert et al., 2006).

The third serious aspect concerning the prevalence of $C$. botulinum in Polish honey, is the number of spores. The spores are mostly type $A$, and to lesser extent, type B. Both are most frequently found involved in infant botulism (Arnon, 1998). Non-illness related honey range from <1 spore to 60 spores/g, while in honey associated with illness the number of spores may be as low as 5 to 70 spores/g (Arnon et al., 1979; Nevas et al., 2005). For these reasons, the number of spores found in a gram of honey is crucial from an epidemiological point of view. The previously mentioned world review of 15 microbial surveys of 2033 honey samples, showed that the honey samples showed contamination at the level of $\leq 1-80$ spores/ 1 gram (Snowdon \& Cliver, 1996). Our finding of an average number of Clostridium spp. spores for 6 types of honey, ranged from 1 to 1800 at the average level of 190 per $1 \mathrm{gram}$ (Fig.1), similar to an average of 180 spores in 1 gram observed in 
Poland by Kędzia and Hołderna-Kędzia (2008). These results seem to be clearly higher than the mentioned world average.

Interestingly the number of Clostridium spp. spores in honeydew honey, nectar-honeydew honey, linden honey, acacia honey, and rape honey ranged from 20 to 540 in a $1 \mathrm{~g}$ sample (Fig. 1), and in multifloral honey the average number of spores in $1 \mathrm{~g}$ ranged from $10-1800$. These results indicate differences that may be due to number of spores between 6 different types of Polish honey showed no statistically significant differences. When comparing some data from USA, for example, from 5 - 80 or even up to 12.500 spores in $1 \mathrm{~g}$, and data from Argentina - up to 55/g (Midura et al., 1979; Gilbert et al., 2006), the level of Polish honey contamination with Clostridium spp. spores is seen to be at a respectively high level. Thus, the fact that the quantity of spores in different types of honey

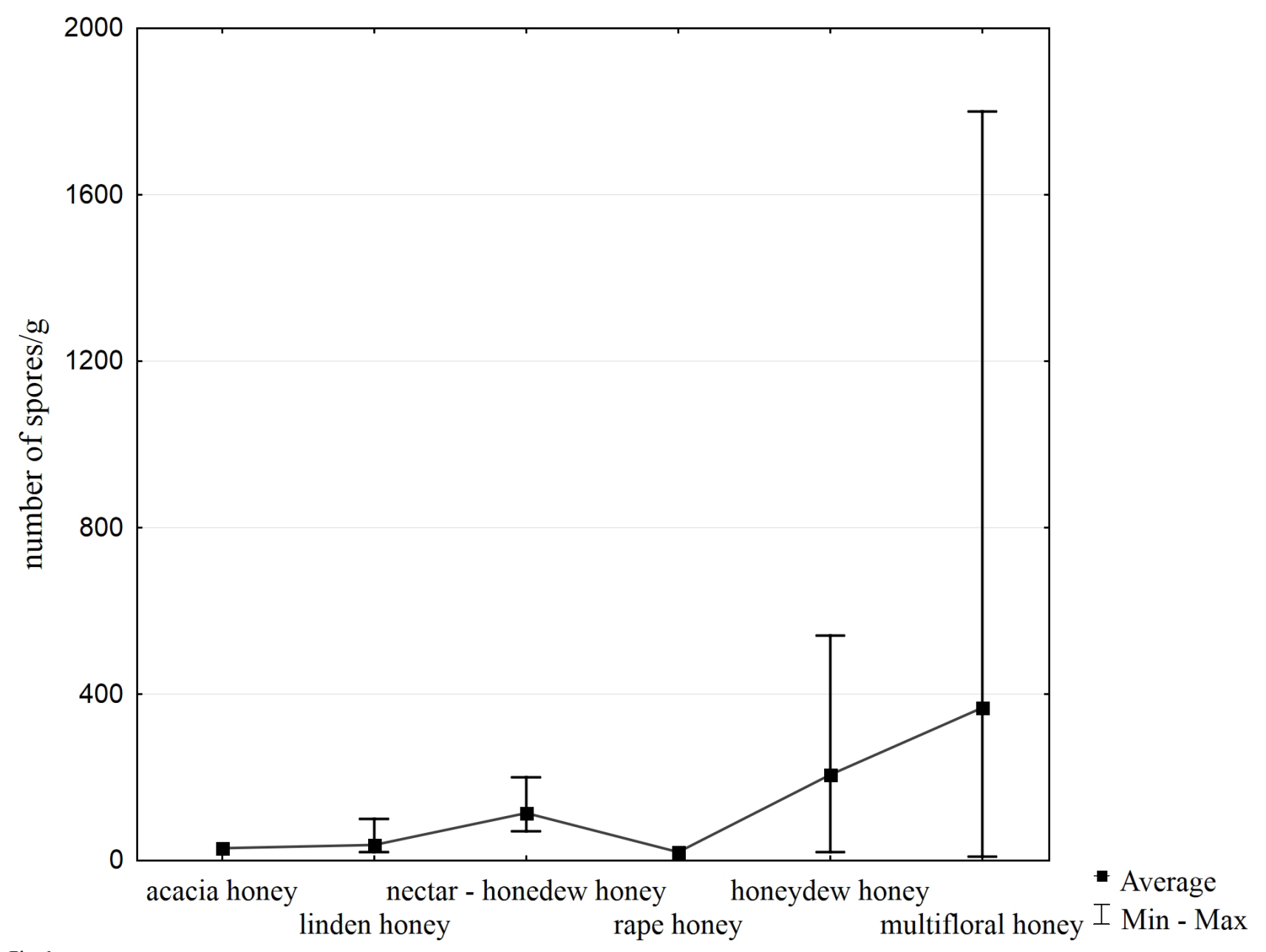

Fig.1.

Occurrence of Clostridium spp. spores in different types of honey

the large variety of flowers (close to the soil surface) nectar collected from multifloral honey tends to be highly contaminated. This conclusion finds support in the fact that the prevalence of C. botulinum spores found in unwrapped linden flowers that were several feet above the soil surface was lower (Bianco et al., 2009) than that detected in the small medical plants (Satorres et al., 1999). However, analysis of the average drastically varied from 10 to 1800 spores/g. of honey, an infant botulism risk assessment must be based on an individual honey sample examination.

A relationship between the prevalence of different serotypes of $C$. botulinum spores in honey samples from small Polish apiaries supports an epidemiological assessment of threat to humans and animals, from C. botulinum 
in areas surrounding these apiaries. In other words honeybee colonies can serve as an indicator of environmental chemical pollution as well as an indicator of $C$. botulinum contamination of the environment.

\section{REFERENCES}

Arnon, S.S., Midura, T.F., Damus, K., Thompson, B., Wood, R.M., Chin, J. (1979). Honey and other environmental risk factors for infant botulism. The Journal of Pediatrics, 94(2), 331-336. http://doi.org/10.1016/ S0022-3476(79)80863-X

Arnon, S.S. (1998). Infant botulism. In Textbook of pediatric infectious diseases. (pp. 1758-1766). Philadelphia: Elsevier Inc.

Arnon, S.S., Schechter, R., Inglesby, T.V., Henderson, D.A., Bartlett, J.G., Ascher, M.S., ... Tonat, K. (2001). Botulinum toxin as a biological weapon: medical and public health management. The Journal of the American Medical Association, 285(8), 1059-1070. http://doi.org/10.1001/jama.285.8.1059

Aureli, P., Franciosa, G., \& Fenicia, L. (2002). Infant botulism and honey in Europe: a commentary. The Pediatric Infectious Disease Journal, 27(9), 866-868. http://doi.org/ 10.1097/01. inf.0000027418.41135.3f

Babapour, A., Razavilar, V., Arzanlou, M., Khazdouzm, A. (2015). Study on prevalence of humen toxogenic types $(A, B, E)$ of $C$. botulinum by nested PCR method in domestic and commercial honeys in Ardebil (Northwest of Iran). International Journal of Biology, Pharmacy and Allied Sciences, 4(2), 334-346.

Bianco, M.I., Luquez, C., de Jong, L.I.T., Fernanadez, R.A. (2009). Linden flower ( Tilia spp.) as potential vehicle of Clostridium botulinum spores in the transmission of infant botulism. Revista Argentina de Microbiologia, 47(4), 232-236.

Brook, I. (2007). Infant botulism. Journal of Perinatology, 27, 175-180. http://doi.org/10.1038/ sj.jp.7211651
Ciećko, Z., Wyszkowski, M., Krajewski, W., Zabielska J. (2001). Effect of organic matter and liming on the reduction of cadmium uptake from soil by triticale and spring oilseed rape. Science of The Total Environment, 2819(1-3), 37-45. http://doi.org/10.1016/ s0048-9697(01)00800-2

Critchley, E.M. (1991). A comparison of human and animal botulism: a review. Journal of the Royal Society of Medicine, 84(5), 295-298. http://doi. org/10.1177/014107689108400517

Dahlenborg, M., Borch, E. \& Radstro, P. (2001). Development of a combined selection and enrichment PCR procedure for Clostridium botulinum types B, E, and $F$ and its use to determine prevalence in fecal samples from slaughtered pigs. Applied and Environmental Microbiology, 6710), 4781-4788. http://doi. org/10.1128/AEM.67.10.4781-4788.2001

Estevinho, L.M., Feás, X., Seijas, J.A., Vazquez-Tato M.P. (2012). Organic honey from Trás-Os-Montes region (Portugal): Chemical, palynological, microbiological and bioactive compounds characterization. Food and Chemical Toxicology, 50(2), 258-264. http://doi. org/10.1016/j.fct.2011.10.034

Gale, P., Drew, T., Phipps, L.P., David, G., Wooldridge M. (2009). The effect of climate change on the occurrence and prevalence of livestock diseases in Great Britain: a review. Journal of Applied Microbiology, 106(5), 1409-1423. http://doi.org/10.1111/j.1365$2672.2008 .04036 . x$

Gilbert, S., Lake, R., Hudson, A., Cressey P. (2006). Risk profile: C. botulinum in honey. Institute of Environmental Science \& Research Limited. Christchurch Science, Centre New Zeeland. Retrieved May 1, 2016, from http://www.foodsafety. govt.nz/elibrary/industry/Risk_Profile_ClostridiumScience_Research.pdf

Horowitz, B.Z. (2005). Botulinum toxin. Critical Care Clinics, 21(4), 825-839. http://doi.org/10.1016/j. ccc.2005.06.008

Huhtanen, C.N., Knox, D. \& Shimanuki H. (1981). Inci- 
dence and origin of Clostridium botulinum spores in honey. Journal of Food Protection, 44(11), 812-814

Huss, H.H. (1980). Distribution of Clostridium botulinum. Applied and Environmental Microbiology, 39(4), 764-769.

Johannsen, A. (1963). Clostridium botulinum in Sweden and the adjacent waters. Journal of Applied Bacteriology, 26(1):43-7.

Kędzia, B., \& Hołderna-Kędzia, E. (2008). Miód. Skład i właściwości biologiczne. Warszawa: PW „Rzeczpospolita" SA.

Kędzia, B., \& Hołderna-Kędzia, E. (2010). Lecznicze działanie miodu pszczelego w chorobach wewnętrznych. Wrockaw: MedPharm Polska.

Koluman, A., Melikoglu Golcu, B., Derin, O., Ozkok, S., Anniballi F. (2013). Clostridium botulinum in honey: prevalence and antibiotic susceptibility of isolated strains. Turkish Journal of Veterinary and Animal Sciences, 37, 706-711. http://doi.org/10.3906/vet$1209-40$

Küplülü, Ö., Göncüoğlu, M., Özdemir, H., Koluman A. (2006). Incidence of Clostridium botulinumspores in honey in Turkey. Food Control, 7入3), 222-224. http:// doi.org/10.1016/j.foodcont.2004.10.004

Lindström, M., \& Korkeala, H. (2006). Laboratory diagnostics of botulism. Clinical Microbiology Reviews, 192), 298-314.http://10.1128/CMR.19.2.298314.2006

Loncaric, I., Ruppitsch, W., Licek, E., Moosbeckhofer, R., Busse, H.J., Rosengarten, R. (2011). Characterization of selected Gram-negative non-fermenting bacteria isolated from honey bees (Apis melifera carnica). Apidologie, 42(3), 312-325, http://doi.org/10.1007/ s13592-011-0019-7

Long, S.S. (2001). Infant botulism. The Pediatric Infectious Disease Journal, 207), 707-709.

Luquez, C., Bianco, M.l., de Jong, L.I.T., Sagua, M.D., Arenas, G.N., Ciccarelli, A.S., Fernandez, R.A. (2005).
Distribution of botulinum toxin-producing Clostridia in soils of Argentina. Applied and Environmental Microbiology, 77(7), 4137-4139. http://doi.org/10.1128/ AEM.71.7.4137-4139.2005

Madras-Majewska, B., Nowakowska, A., \& Rosiak E. (2014). Evaluation of microbial quality of imported honeys available on the Warsaw market. In Proceedings of International Symposium on Bee Products 3rd Edition, Annual meeting of the International Honey Commission (IHC) (p. 117). Opatija - Croatia.

Midura, T.F., Snowden, S., Wood, R.M., Arnon SS. (1979). Isolation of Clostridium botulinum from honey. Journal of Clinical Microbiology, 9(2), 282-283.

Myllykoski, J., Nevas, M., Lindström, M., Korkeala, H. (2006). The detection and prevalence of Clostridium botulinum in pig intestinal samples. International Journal of Food Microbiology, $710(2), 172-177$. http:// doi.org/ 10.1016/j.jfoodmicro.2006.04.017

Nakano, H., Kizaki, H., \& Sakaguchi G. (1994). Multiplication of Clostridium botulinum in dead honey-bees and bee pupae, a likely source of heavy contamination of honey. International Journal of Food Microbiology, 27(3), 247-252. http://doi.org/10.1016/01681605(94)90031-0

Nevas, M., Lindström, M., Hautamäki, K., Puoskari, S., Korkeala, H. (2005). Prevalence and diversity of Clostridium botulinum types A, B, E and F in honey produced in the Nordic countries. International Journal of Food Microbiology, 105(2), 145-151. http://doi. org/ 10.1016/j.ijfoodmicro.2005.04.007

Nevas, M. (2006). Clostrıdium botulinum in honey production with respect to infant botulism. Academic Dissertation, Department of Food and Environmental Hygiene, Faculty of Veterinary Medicine, University of Helsinki, Helsinki, Finland, Retrieved May 1, 2016, from https://helda.helsinki.fi/bitstream/ handle/10138/18964/clostrid.pdf

Nevas, M., Lindström, M., Hörman, A., KetoTimonen, R., Korkeala H. (2006). Contamination routes of Clostridium botulinum in the honey production environment. Environmental Microbiol- 
ogy, 8(6), 1085-1094. http://doi.org/10.1111/j.14622920.2006.01000.x

Palacio, A.M., Figini, E.F., Ruffinengo, S.R., Rodriguez, E.M., del Hoyo, M.L., Bedascarrasbure, E.L. (2000). Changes in a population of Apis mellifera L. selected for hygienic behaviour and its relation to brood disease tolerance. Apidologie, 37(4), 471-478. http:// doi.org/10.1051/apido:2000139

PN-88/A-77626. (1988). Miód pszczeli. Warszawa: Wydawnictwo Normalizacyjne Alfa.

Roman, A., Popiela-Pleban, E., \& Kozak M. (2013). Factors influencing consumer behavior relating to the purchasing of honey. Part 1. The buying process and the level of consumption. Journal of Apicultural Science, 572), 159-172. http:///doi.org/ 10.2478//AS2013-0026

Różańska. H. (2011). Microbiological quality of Polish honey. Bulletin of the Veterinary Institute in Pulawy, 55(3), 443-445.

Rudnicka, K., Tenderenda, M., \& Chmiela, M, (2013). Etiologia i epidemiologia botulizmu niemowląt. Pediatria Polska, 89(3),198-202. http:// doi:10.1016/j. pepo.2013.10.003

Rudnicka, K., Kwiatkowska, P., Gajewski A., Chmiela M., (2015). Mikroflora miodu jako źródło spor C. botulinum i przyczyna rozwoju botulizmu niemowląt rozważania na temat zasadności oczyszczania miodu w kontekście obowiązującego prawa. Postępy Mikrobiologii, 54(2), 184-194.

Satorres, S.E., Alcaraz, L.E., Fernández, R.A., Centorbi, O.N. (1999). Isolation of Clostridium botulinum in medical plants. Anaerobe, 5(3), 173-175. http://doi. org/10.1006/anae.1999.0205

Shapiro, R.L., Hatheway C., \& Swerdlow D.L. (1998). Botulism in the United States. A clinical and epidemiologic review. Annals of Internal Medicine, 129(3), 221-228, http://doi.org/10.7326/0003-4819-1293-199808010-00011
Sharma, S. K., Ferreira, J.L., Eblen, B.S., Whiting R.C. (2006). Detection of type $A, B, E$, and F Clostridium botulinum neurotoxins in foods by using an amplified enzyme-linked immunosorbent assay with digoxigenin-labeled antibodies. Applied Environmental Microbiology, 72(2), 1231-1238. http://doi.org/ 10.1128/AEM.72.2.1231-1238.2006

Smith, LD. (1979). Clostridium botulinum. characteristics and occurrence. Clinical Infectious Diseases, 7(4), 637-641. http://doi.org/10.1093/clinids/1.4.637

Snowdon, J. A., \& Cliver, D.O. (1996). Microorganisms in honey. International Journal of Food Microbiology, 37(1-3), 1-26. http://doi.org/10.1016/01681605(96)00970-1

Spivak, M., \& Downey, D.L. (1998). Field assays for hygienic behavior in honey bees (Hymenoptera: Apidae). Journal of Economic Entomology, 97(1), 64-70. http://doi.org/10.1093/jee/91.1.64.

Stämpfli, H.R. (2014). Botulism. In The Merck Veterinary Manual. Retrieved May 1, 2016, from http:// www.merckvetmanual.com/mvm/index.html

Volkova, V.P., \& Siniak, K.M. (1989). The possibility of the germination of spores of pathogenic clostridia and bacilli in soil. Izvestiia Akademiil Nauk SSSR. Seriia Biologicheskaia, 5, 791-795.

Wells, C.L., \& Wilkins, T.D. (1996). Clostridia: Sporeforming Anaerobic Bacilli. In Medical Microbiology. Texas: Galveston, Retrieved May 1, 2016, from http:// www.ncbi.nlm.nih.gov/books/NBK8219/

Woudstra, C., Skarin, H., Anniballi, F., Fenicia, L., Bano, L., Drigo, I., Koene, M., Bäyon-Auboyer, M.H., Buffereau, J.P., De Medici, D., Fach P. (2012). Neurotoxin gene profiling of Clostridium botulinum types $\mathrm{C}$ and D native to different countries within Europe. $A p$ plied and Environmental Biology, 78(9), 3120-3127.

\section{http://doi.org/10.1128/AEM.07568-11}

WHO (2013). Botulism. Fact sheet No 270. Retrieved May 1, 2016, from http://www.who.int/mediacentre/factsheets/fs270/en/ 


\section{_ WDJTRKKH Et fl. _ Prevalence of $C$. botulinum spores in honey}

Yule, A.M., Barker, I.K., Austin, I.W., Moccia, R.D. (2006). Toxicity of Clostridium botulinum type E neurotoxin to Great Lakes fish: implications for avian botulism. Journal of Wildlife Diseases, 42(3), 479-93. http:// dx.doi.org/10.7589/0090-3558-42.3.479 